\title{
Prevention of trace element deficiencies in grazing ruminants: an evaluation of methods
}

\author{
AgResearch Grasslands, Private Bag 11008, Palmerston North
}

\begin{abstract}
The prevention of cobalt, copper, selenium and iodine deficiencies is an important feature of stock health programmes on many New Zealand farms. Various methods of prevention involving direct supplementation to animals and topdressing pastures have been evaluated. Protocols for the amounts administered and frequency of supplementation for $\mathrm{Co}, \mathrm{Cu}, \mathrm{Se}$ and $\mathrm{I}$ have been outlined.
\end{abstract}

Keywords: cattle, cobalt, copper, deficiencies, iodine, deficiencies, prevention protocols, selenium, sheep

\section{Introduction}

Selenium, cobalt, copper and iodine deficiencies are an important feature of the New Zealand livestock industry, and once a trace element deficiency has been diagnosed the most effective method of preventing the deficiency has to be decided on. The options available to increase the intake and improve the mineral status of animals include topdressing the pasture, oral dosing and injections. New technologies such as the controlledrelease systems are being incorporated into new products such as glass boluses which are placed in the rumen and are designed to improve the efficacy of the trace element supplement.

To be effective the supplement must increase and maintain the mineral status of the animal for long periods. The supplements therefore should be given directly to the animal or topdressed on to the grazed pasture to increase the trace element content of the herbage. The use of water troughs or salt blocks as vehicles for trace element supplementation is not satisfactory as the daily intakes of water and salt are highly variable.

\section{Establishment of treatment protocols}

The protocols for the amounts of trace element to be administered and the frequency of administration have been determined from a consideration of (a) the trace element requirements, that is, the daily intakes that are required to ensure an adequate mineral status, good health and maximum productive performance and (b) the trace element status of an animal as assessed from blood trace element levels (e.g. Cu. Se), vitamin concentrations (Co) and enzyme activities ( $\mathrm{Cu}$ and $\mathrm{Se}$ ), as well as the trace element and vitamin contents of the liver.

The observed changes in trace element concentrations when pastures are topdressed or when animals are supplemented will now be discussed and proven methods for the prevention of trace element deficiencies recommended.

\section{Cobalt}

\section{(a) Topdressing pasture}

The application of $350 \mathrm{~g} \mathrm{ha} / \mathrm{CoSO}_{\mathbf{4}} \mathbf{7} \mathrm{H}_{\mathbf{2}} \mathrm{O}$ along with fertiliser causes a rapid increase in pasture Co concentrations (e.g. $0.04 \mathrm{mg}$ to $0.5 \mathrm{mg} / \mathrm{kg} \mathrm{DM}$ ) within $4-6$ weeks which is then followed by a marked decline over the next 4 to 6 weeks $(0.5$ to $0.12 \mathrm{mg} / \mathbf{k g ~ D M})$ and a slower decline $(0.12$ to $0.09 \mathbf{m g} / \mathbf{k g ~ D M})$ during the next 9-10 months (Sherrell 1984). The magnitude of the response is depended on soil type and the soil Co status while $\mathrm{Co}_{0}$ content of clover is higher than that of grasses. Once the Co status of the soil has been increased by regular applications of $\mathrm{Co}$ it is possible to reduced the amounts of Co applied (175g ha/ $\left.\mathrm{CoSO}_{4} .7 \mathrm{H}_{2} \mathrm{O}\right)$ and still maintain adequate pasture Co levels.

To prevent Co deficiencies in weaned lambs, which are most sensitive to Co deficiency, pasture must contain at least $0.1 \mathrm{mg} \mathrm{Co} / \mathrm{kg}$ DM (Clark 1983).

\section{(b) Administration to the animal}

Co deficiency is actually a vitamin $\mathrm{B}_{\mathbf{1 2}}$ deficiency as the rumen micro-organisms require Co to synthesise vita$\min \mathbf{B}_{12}$ which is then absorbed and stored in the liver. From supplementation studies with $C_{0}$ and vitamin $B_{12}$ it has been established that in animals of an adequate $\mathrm{Co}$ status the vitamin $\mathbf{B}_{\mathbf{1 2}}$ concentrations in the serum and liver must be greater than $370 \mathrm{pmol} / \mathrm{l}$ and $220 \mathrm{nmol} / \mathrm{kg}$ fresh tissue respectively (Clarke 1983). Injected Co cannot be converted to vitamin $\mathbf{B}_{\mathbf{1 2}}$ and therefore Co must be administered orally as a drench, a bullet or a soluble glass bolus. 
Table 1 Effect of vitamin $B_{12}$ injections and Co drenches on growth rates and tissue vitamin $B_{12}$ concentrations in lambs.

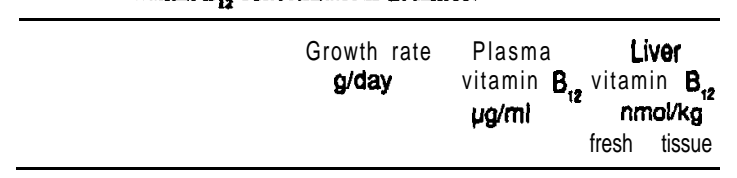

\begin{tabular}{|c|c|c|c|}
\hline \multicolumn{4}{|l|}{ Study A } \\
\hline $\begin{array}{l}\text { No vilamin } \mathbf{B}_{\mathbf{p}} \\
1.0 \mathrm{mg} \text { vitamin } \mathbf{B}_{\mathbf{4}} / \text { month }\end{array}$ & $\begin{array}{l}101 \\
153\end{array}$ & $\begin{array}{l}0.14 \\
0.51\end{array}$ & $\begin{array}{r}140 \\
474\end{array}$ \\
\hline $2.0 \mathrm{mg}$ vitamin $\mathbf{B}_{12} /$ month & 147 & 0.63 & 549 \\
\hline \multicolumn{4}{|l|}{ Study $\mathbf{B}$} \\
\hline No Co drench & 131 & & \\
\hline $1 \mathrm{mg}$ Co/day & 275 & & \\
\hline $7 \mathrm{mg}$ Cowweek & 236 & & \\
\hline $14 \mathrm{mg} \mathrm{Co/2}$ weeks & 194 & & \\
\hline $26 \mathrm{mg}$ Co/month & 149 & & \\
\hline
\end{tabular}

For a 20-25 $\mathrm{kg}$ lamb $1-2 \mathrm{mg}$ of vitamin $\mathrm{B}_{12}$ injected monthly is adequate to promote good weight gains and maintain blood and liver vitamin $B_{12}$ levels. (Hogan et al. 1973). Likewise, daily (1 mg/dose) or weekly (7 mg/ dose) drenching of Co is necessary to ensure good growth but has the disadvantage of being too labour intensive (Stewart et al. 1955). Thereisno doubt that the Co bullet and the soluble glass bolus, releasing $0.6 \mathrm{mg}$ day/Co, are effective in increasing the vitamin $\mathbf{B}_{12}$ content of the liver and blood for 6 to 12 months (Millar et al. 1984). However the NZ experience is that these can be readily regurgitated and lost while those remaining in the rumen become coated with a deposit of $\mathrm{Ca}_{2}(\mathrm{PO}$,$) ,$

\section{Selenium}

\section{(a) Topdressing}

Pastures must contain at least $30 \mathrm{pg}$ Se/kg DM to ensure that a Se deficiency does not occur. Topdressing pasture with $\mathrm{Se}(10 \mathrm{~g} \mathrm{Se} / \mathrm{ha})$ will rapidly increase the Se concentrations from 20 to over $600 \mu \mathrm{g} \mathrm{Se} / \mathrm{kg} \mathrm{DM}$ in about 8 weeks followed by a marked decline $(600-50 \mathrm{pg} \mathrm{Se} / \mathrm{kg}$ DM) over the next 2-3 months and then a slower decline over 8-10 months (50-20 $\mu \mathrm{g} \mathrm{Se/kg} \mathrm{DM)} \mathrm{(Watkinson}$ 1983). Animals grazing these pastures also show marked changes in blood Se levels as these increase from 125 to over $2500 \mathrm{nmol} / 1$ after 3 months' grazing Se-treated pasture. The blood level then slowly declines over the next 9 months (2500-250 nmol/n) (Watkiion 1983). Thus Se topdressing of deficient pastures with sodium selenate $\left(\mathrm{Na}_{2} \mathrm{SeO}_{4} \cdot 10 \mathrm{H}_{2} \mathrm{O}\right)$ will maintain an adequate $\mathrm{Se}$ status of grazing animals for 12 months.

The whole area of the farm need not be topdressed with Se, as strategic grazing can maintain the Se status of all animals because adequate amounts of Se can be 'stored' after 16 weeks of grazing a Se-treated pasture to maintain blood Se levels for another 3040 weeks.

\section{Treatment of animals}

The Se status of sheep and cattle are considered to be adequate when the blood and liver Se concentrations are above $250 \mathrm{nmol} / \mathrm{h}$ and $450 \mathrm{nmol} / \mathrm{kg}$ fresh tissue respectively (Clark 1983).

Table2 Effect of Se given orally as a drench, a Fe/Se bullet and a soluble glass bolus or as an injection of $\mathrm{Ba}$ selenste on the blood Se (nmol/n) concentrations in sheep.

\begin{tabular}{|c|c|c|c|}
\hline Days after treatment & 10 & 50 & 100 \\
\hline \multicolumn{4}{|l|}{ Study A } \\
\hline $\begin{array}{l}\text { No Se drench } \\
\text { oral drench } \mathrm{Na}, \mathrm{S} 0 \mathrm{O}, 10 \mathrm{H}, \mathrm{O}\end{array}$ & 65 & 65 & 65 \\
\hline$(0.1 \mathrm{mg} \mathrm{Se} / \mathrm{kg} \mathrm{LW})$ & 630 & 500 & 360 \\
\hline \multicolumn{4}{|l|}{ Study $\mathbf{B}$} \\
\hline No Se given & $\begin{array}{r}260 \\
1500\end{array}$ & $\begin{array}{r}250 \\
3200\end{array}$ & $\begin{array}{r}250 \\
3600\end{array}$ \\
\hline $\begin{array}{l}(5 \% \text { Se } 95 \% \mathrm{Fe}) \\
\text { releasing } 0.5-\mathrm{I} \quad \mathbf{3} \mathrm{mg} \text { Se/day }\end{array}$ & & & \\
\hline $\begin{array}{l}\text { Soluble glass bolus releasing } \\
0.35 \mathrm{mg} \text { Se/day }\end{array}$ & 400 & 1600 & 2000 \\
\hline \multicolumn{4}{|l|}{ Study C } \\
\hline $\begin{array}{l}\text { No Se given } \\
\text { injected as BaSeO, } \\
\text { (1 } \mathrm{mg} \mathrm{Se} / \mathrm{kg} \mathrm{LW} \text { ) }\end{array}$ & 215 & $\begin{array}{r}215 \\
4900\end{array}$ & $\begin{array}{r}215 \\
4200\end{array}$ \\
\hline
\end{tabular}

Although in sheep the response curves after 2 days for blood Se were similar for animals either drenched or injected, the blood Se levels always remained a little higher for the injected animals. The Se given as a drench or injection will maintain Se blood levels for at least 34 months. As the glass boluses were observed to be readily expelled by sheep ( $50 \%$ lost in 4 months) they are not satisfactory. The same problem has also been observed in sheep for the Se bullet (Miller et al. 1984). The Ba selenate injection gave very high blood Se levels peaking at 100-150 days (4200 $\mathrm{nmol} / \mathrm{l})$ and then declined to $1428 \mathrm{nmol} / \mathrm{l} 360$ days after the injection (Metherell et al. 1984).

\section{Copper}

\section{(a) Topdressing pasture}

The effectiveness of increasing the Cucontent of pasture by the application of $\mathrm{Cu}$ salts depends on the composition of the pasture and soil type (Sherrell \& Rawnsley 1982). The uptake of $\mathrm{Cu}$ and its persistence by clover is greater than for the grasses.

In contrast to Co and Se which are not essential elements for plant growth, pasture DM responses to $\mathrm{Cu}$ havebeenobserved (Sherrell1982). An applicationof 2 $4 \mathrm{~kg} \mathrm{Cu} / \mathrm{ha}$ as copper sulphate $\left(\mathrm{CuSO}_{4}, 5 \mathrm{H}_{2} \mathrm{O}\right)$ increases 
herbage $\mathrm{Cu}$ concentration from 5-12 $\mathrm{mg} / \mathrm{kg}$ DM within 4 weeks and then it decreases markedly to $8 \mathrm{mg} / \mathrm{kg} \mathrm{DM}$ followed a slow decline over the next 9-10 months (Cunningham et al. 1946).

At pasture $\mathrm{Mo}$ and $\mathrm{Fe}$ concentrations of below $1 \mathrm{mg}$ Mo/kg DM and $300 \mathrm{mg} \mathrm{Fe} / \mathrm{kg}$ DM. the Curequirements of sheep and cattle are met by pasture $\mathrm{Cu}$ levels of 5-6 $\mathrm{mg} / \mathbf{k g ~ D M}$ and $8-9 \mathrm{mg} / \mathbf{k g}$ DM respectively (Grace 1983; Grace \& Lee 1990). As the $\mathrm{Cu}$ requirements of cattle are greater than for sheep increases the concentrations of pasture $\mathrm{Mo}$, in presence of $\mathrm{S}$, and $\mathrm{Fe}$ have a greater influence on the $\mathrm{Cu}$ status of cattle. If the pasture Mo concentrations exceed 2-3 mg Mo/kg DM, then topdressing with $\mathrm{Cu}$ may not be effective in increasing pasture $\mathrm{Cu}$ levels to ensure that the $\mathrm{Cu}$ :Mo ratio is greater than 3 .

\section{(b) Treatment of animals}

$\mathrm{Cu}$ can be administered to animals orally or as an injection. The best indicator of the $\mathrm{Cu}$ status of sheep and cattle is the change in the liver $\mathrm{Cu}$ concentrations because SO-60\% of the body $\mathrm{Cu}$ can be found in the liver. An adequate $\mathrm{Cu}$ status is reflected by liver and blood $\mathrm{Cu}$ concentrations of greater than $20 \mathrm{mg} \mathrm{Cu} / \mathrm{kg}$ DM $(95$ $\mu \mathrm{mol} / \mathrm{kg}$ fresh tissue) and $8 \mu \mathrm{mol} / /$ respectively.

A marked seasonal variation in liver $\mathrm{Cu}$ concentrations occurs with levels being lowest during the winter. Drenching sheep with $300 \mathrm{mg} \mathrm{Cu}$ has a short term effect on $\mathrm{Cu}$ status, with no difference observed between untreated and treated animals after 49 days. Treatment with $\mathrm{CuO}$ needles and $\mathrm{Cu}$ injections maintained elevated liver $\mathrm{Cu}$ levels for 180-200 days.
More severely $\mathrm{Cu}$-deficient animals would be protected for a shorter period (Langlanda et al. 1986).

\section{Iodine}

\section{(a) Topdressing}

The application of I salts (e.g. KI or KIO,) to pasture as a way of increasing the I intake is not satisfactory as these salts are expensive and decompose on storage. To prevent I deficiency, in absence of a goitrogen. the diet should contain at least $0.2 \mathrm{mg} \mathrm{I} / \mathrm{kg} \mathrm{DM}$.

\section{(b) Treatment of the animal}

To date an evaluation of the efficacy of I supplementation as been done usually through observations on animal performance. Iodine deficiency has been diagnosed from the incidence of enlarged thyroids (Sinclair \& Andrews 1961). It has been well documented that treatment of pregnant ewes fed brassica crops 8 and 4 weeks before lambing with 280 potassium iodide or 360 $\mathrm{mg}$ potassium iodate will prevent (Sinclair \& Andrews 1958) I deficiency in the lambs. Likewise a $1 \mathrm{ml}$ intramuscular injection with iodised oil $(475 \mathrm{mg} \mathrm{I} / \mathrm{ml})$ protects sheep for at least 3 years against I deficiency (Sinclair \& Andrews 1961).

\section{Treatment protocol to prevent $\mathrm{Co}, \mathrm{Se}, \mathrm{Cu}$ and I deficiencies}

From the data presented here together other information on tissue mineral concentrations and animal perform-

Table 3 Effect of $\mathbb{C}$ given orally as a drench, CuO needles and as an injection on liver $\mathrm{Cu}$ concentrations (mg Cu/kg DM) of sheep or cattle

\begin{tabular}{|c|c|c|c|c|c|}
\hline \multirow[b]{2}{*}{ Days after treatment } & \multicolumn{2}{|c|}{ Sheep } & \multirow[b]{2}{*}{101} & \multirow[b]{2}{*}{271} & \multirow[b]{2}{*}{355} \\
\hline & 0 & 49 & & & \\
\hline \multicolumn{6}{|l|}{ Study A hoggets (45 kg LW) } \\
\hline No $\mathrm{Cu}$ & 47 & 47 & 56 & 126 & 163 \\
\hline $300 \mathrm{mg} \mathrm{Cu}$ oral & 46 & 69 & 61 & 144 & 175 \\
\hline \multicolumn{6}{|l|}{ Study B lambs (21 kg LW) } \\
\hline No Cu & 307 & 369 & 366 & 264 & 382 \\
\hline $2.5 \mathrm{gcuO}$ oral & 239 & 796 & 727 & 313 & 401 \\
\hline \multirow{2}{*}{$\begin{array}{l}50 \mathrm{mg} \mathrm{Cu} \text { Ca-edetate } \\
\text { subcutaneously }\end{array}$} & 272 & 849 & 606 & 324 & 448 \\
\hline & \multicolumn{2}{|c|}{ Cattle } & & & \\
\hline Days from treatment & 0 & 50 & 100 & 245 & 888 \\
\hline Study C (cows 327 kg LW) & & & & & \\
\hline No Cu & 77 & 95 & 104 & 117 & 142 \\
\hline $40 \mathrm{~g}$ CuO oral & 89 & 225 & 296 & 209 & 181 \\
\hline $\begin{array}{l}150 \mathrm{mg} \mathrm{Cu} \text { Ca-edetate } \\
\text { subcutaneously }\end{array}$ & 73 & 154 & 151 & 182 & 155 \\
\hline
\end{tabular}


ance the following supplement protocols are recommended to prevent trace element deficiencies in sheep and cattle. The information can also be extended to deer and goats provided that it is realised their trace element requirements have not been so well defined.

\section{Cobalt}

(1) Topdress pasture with $350 \mathrm{~g}$ cobalt sulphate/ha/yr.

(2) Sheep: Lambs inject with 1-2 $\mathrm{mg}$ vitamin $B_{12}$ every 4-6 weeks.

(3) Cattle: Calves inject with $2 \boldsymbol{m g}$ vitamin $B_{12}$ every 46 weeks.

\section{Selenium}

(1) Topdress pasture with $10 \mathrm{~g} \mathrm{Se} / \mathrm{ha} /$ year as sodium selenate $\left(\mathrm{Na}_{2} \mathrm{SeO}_{4} \cdot 10 \mathrm{H}_{2} \mathrm{O}\right)$.

(2) Sheep: Ewes inject or dose $5 \mathrm{mg} \mathrm{Se} / \mathrm{animal}$ as $\mathrm{Na}$ selenate 3-4 weeks before mating and lambing. Lambs inject or dose 1-2 mg Se/animal as $\mathrm{Na}$ selenate at docking and thereafter 3-4 $\mathrm{mg} \mathrm{Se}$ at 2monthly intervals.

(3) Cattle: Inject with $0.1 \mathrm{mg} \mathrm{Se} / \mathrm{kg}$ liveweight using $\mathrm{Na}$ selenate every 2-3 months.

(4) Sheep and cattle: Inject with $\mathrm{BaSeO}_{4}(1 \mathrm{mg} / \mathrm{kg}$ liveweight)4-6 weeks before mating annually.

\section{Copper}

(1) Topdress pasture $5 \mathrm{~kg}$ copper sulphate $(1 \mathrm{~kg}$ cop$\mathrm{ped} / \mathrm{ha} / \mathrm{year}$.

(2) Sheep: Ewes dose with $2-4 \mathbf{g ~ C u O}$ needles every 612 months.

Lambs dose with 1-2 g Cuo needles every 6-12 months.

(3) Cattle: Cows dose with $10-30 \mathrm{~g} \mathrm{CuO}$ needles every 6-12 months.

Inject $120-240 \mathrm{mg} \mathrm{Cu}$ at 4-8 months.

Iodine

(1) Sheep: Ewes dose with $250 \mathrm{mg}$ potassium iodide or $300 \mathrm{mg}$ potassium iodate 8 and 4 weeks before lambing.

Inject with $1 \mathrm{ml}$ iodised oil every 3 years.

(2) Cattle: Cows inject with $4 \mathrm{ml}$ iodised oil every 2 years.

\section{REFERENCES}

Clark, R.C. 1983. Diagnostic data as a basis for mineral therapy in poor lamb growth. pp193-212. In Lamb Growth. A.G. Familton (ed). Animal Industries Workshop. Lincoln College,
Cunningham. I.J.; Perrin, D.D. 1946. Copper compounds as fertilizers for pastures deficient in copper. New Zealand journal of science and technology 28: 252-265.

Grace, N.D. 1983. Copper Cu. In The mineral requirements of grazing ruminants pp56-66. N.D. Grace (ed.). Occasional Publication No. 9. N.Z. Society of Animal Production.

Grace.N.D.; Lee, J. 1990. Effect of increasing Fe intake on the $\mathrm{Fe}$ and $\mathrm{Cu}$ content of tissues in grazing sheep. Proceedings New Zealand Society of Animal Production 30: 265-268.

Hogan, K.G.; Lorentz, P.P.; Gibb, F.M. 1973. The diagnosis and treatment of vitamin $\mathbf{B}_{12}$ deficiency in young lambs. New Zealand veterinary journal 21 : 234-237.

Langlands, J.P.; Donald, G.E.; Bowles, J.E.;Smith,A.J. 1986. Trace element nutrition of grazing ruminants. II Hepatic copper storage in young and adult sheep and cattle given varying quantities of oxidized copper particles and other copper supplements. Australian journal agricultural research.

Metherell, A.K.; Owens, J.L.; Mackintosh, C.G.; Turner, K. 1984. Selenium supplementation alternatives: their effects on animal production, glutathione peroxidase and selenium levels in ewes and lambs pp.88-89. In Trace Elements in the Eighties. Proceedings of the NZ Trace Element Group, Massey Universitv.

Millar, K.R.; Meads, W.J.; Albyt. A.I. 1984: Slow release 'devices' for correcting trace element deficiencies in sheep pp.108-109. In Trace elements in the eighties. Proceedings of the N.Z. Trace Element Group, Massey University.

Sherrell. C.G.; Rawnsley, J.S. 1982. Effect of copper application on copper concentration in white clover and perennial ryegrass on some Northland soils and a yellow-brown pumice soil. New Zealand of agricultural research 25: 363-368.

Sherrell. C.G. 1984. Cobalt deficiency topdressing recommendations. Aglink FPP 814. Ministry of Agriculture and Fisheries.

Sinclair, D.P.; Andrews, E.D. 1958. Prevention of goitre in new-born lambs from kale-fed ewes. New Zealand veterinary journal 6: 87-95.

Sinclair, D.P.; Andrews. E.D. 1961. Deaths due togoitre in new-born lambs prevented by iodized poppyseed oil. New Zealand veterinary journal 9: 96100

Stewart, J.; Mitchell, LW.; Young, F.J. 1955. Cobalt therapy in farm practice with special reference to kill farms. Veterinary record 67: 755-757.

Watkinson. J.H. 1983. Prevention of selenium deficiency in grazing animals by annual topdressing of pasture with sodium selenate. New Zealand veterinary journal 31: 78-85. 